\title{
Cochliobolus, Drechslera, Bipolaris, Curvularia different nomenclature for one potent fungus
}

\author{
Waill A. Elkhateeb ${ }^{1 *}$, Abdu Ghalib AL Kolaibe ${ }^{2}$, Ghoson M. Daba ${ }^{1}$ \\ ${ }^{1}$ Chemistry of Natural and Microbial Products Department, Pharmaceutical Industries Division, National Research Centre, Dokki, Giza, 12622, Egypt. \\ ${ }^{2}$ Microbiology Department, Faculty of science, Taiz University, Taiz, Yemen. \\ Corresponding Author: Waill A. Elkhateeb, Department of Pharmaceutical Industries Division, National Research Centre, Dokki, Giza, \\ 12622, Egypt. \\ Received date: January 25, 2021; Accepted date: January 28, 2021; Published date: February 04,2021 \\ Citation: Waill A. Elkhateeb, Abdu G. AL Kolaibe, Ghoson M. Daba (2021) Cochliobolus, Drechslera, Bipolaris, Curvularia different nomenclature \\ for one potent fungus J. Pharmaceutics and Pharmacology Research 4(1); DOI: 10.31579/2693-7247/031
}

Copyright: () 2021, Waill A. Elkhateeb, This is an open access article distributed under the Creative Commons Attribution License, which permits unrestricted use, distribution, and reproduction in any medium, provided the original work is properly cited.

\begin{abstract}
Cochliobolus is a Dematiaceous fungi that belong to family: Pleosporaceae. It is known as worldwide pathogen of mostly grasses that caused devastating disease epidemics of important economic food crops as wheat, rice, and maize. Many Cochliobolus species have their asexual states, and consequently synonyms, in either Bipolaris or Curvularia. In this review, highlights were presented on Cochliobolus species as models of fungi rich in therapeutic agents that can be employed in different applications. Moreover, describing the importance and potentials of this fungus in order to encourage for further studies to search, isolate, and purify already known metabolites. Also, screen for, and discover novel metabolites produced by those potent fungi in order to be involved in additional applications.
\end{abstract}

Keyword: cochliobolus; secondary metabolites; biological activities

\section{Introduction}

Natural products represent the significant and important source for discovery of potential novel drugs. The search for novel secondary metabolites is currently focusing on endophytic microorganisms isolated from plants, remote locations, and novel sources. Numerous reports shows that endophytes produce a wide variety of chemical substances, many of which show biological activity [1-3].

There are various uses of the numerous promising secondary metabolites produced by fungal endophytes. The application of microbial secondary metabolites in various fields of biotechnology has attracted the interests of many researchers. Bioactive compounds have various applications in pharmacology and agriculture [4]. Cochliobolus species are heterothallic fungi that found mainly in soil and organic compost and they are noted for the production of secondary metabolites with vital biological activities [5-8].

The microorganisms such as Cochliobolus may be very interesting for biotechnological production of bioactive substances as medicinally important agents. The endophytic fungus Cochliobolus sp. this fungus possess significant antioxidant, antidiabetic and anti-inflammatory potentials [9-11].

The previous studies reported that Cochliobolus sp. produce many important secondary metabolites cluding curvularides, anthraquinones, cochlioquinones, helminthosporal, helminthosporol, prehelminthosporol as well as various related metabolites. These compounds exhibit many pharmacological importances, due to their antioxidant, antimicrobial as well as antifungal properties. Hence, screening and identification of fungal endophytes s very important as a source for novel natural products. Fascinatingly, it seems that the host-endophytic interaction plays a crucial role in the direction of the endophytes secondary metabolites production $[12,13]$.

\section{Cochliobolus description and ecology}

Endophytes are microorganisms located in internal layers of living plants without being harmful to the plant. There are many remarkable pharmacological agents that are continuously explored and identified from endophytic fungi [14]. It should be mentioned that over $50 \%$ of identified bioactive compounds have been isolated from fungal endophytes [15]. Endophytic fungi are the source of many pharmaceutical compounds including those exerting antibacterial, antifungal, anticancer, antitumor, antiviral, and anti-inflammatory activities [16, 17].

Genus Cochliobolus is a fast growing fungus attaining $5.5 \mathrm{~cm}$ diameter after 5 days on Czapek's Agar and Malt Agar. Genus Cochliobolus belong to Phylum Ascomycota; Class: Dothideomycetes; Order: Pleosporales; Family: Pleosporaceae. The genus Cochliobolus (as well as its anamorphic sp. that almost include nearly 55 species (Bipolaris, Curvularia) are found worldwide. These species are weeds pathogens and since the weeds and pathogens are coevolved over long term, these species can be applied as weed herbicides [18]. The taxonomy of Cochliobolusis is a little bit confusing due to the frequent changes in nomenclatural that have occurred in the sexual and asexual states of species over the past decades. Cochliobolus ascomata are dark brown to black, unilocular with a globose body and a long or short cylindrical ostiolate neck. Hyaline to brown sterile hyphae and conidiophores often 
occur on the ascomata and less so on the neck [19]. Asci are bitunicate, 2-8-spored, cylindrical toobclavate or obclavate cylindrical .Ascospores are filiform and more or less coiled in a helix in the ascus (Figure 1,2). Most species of Cochliobolus form protothecia (sclerotia) which are sterile without any ascogenoushyphae [20-22]. It is a saprophyte and survives primarily as thick-walled conidia. It can also survive as mycelium in soil or crop debris. The sexual stage is not important in the disease cycle. Primary inoculum includes mycelium from infected seed, conidia in the soil, and conidia on the kernel surface [23]. Cochliobolus species encountered based on conidia different shapes. Conidia straight, conidia curved, conidia wall smooth, conidia curved with 3-distoseptate, conidia wall with tuberculate, conidia with 5 -distoseptate and conidia with 6-10-distoseptate.

Germination of conidia takes place in presence of susceptible hosts and initiate primary infection on the coleoptile, or primary roots. Before penetration, appressoria and dome-shaped infection cushions are formed. Infection pegs form underneath infection cushions and appressoria. Tissue disintegration come as the final step after development of infection from epidermis to cortex then endodermis. Spreading of conidia is causing the progress in colonization of infected plant parts [24].

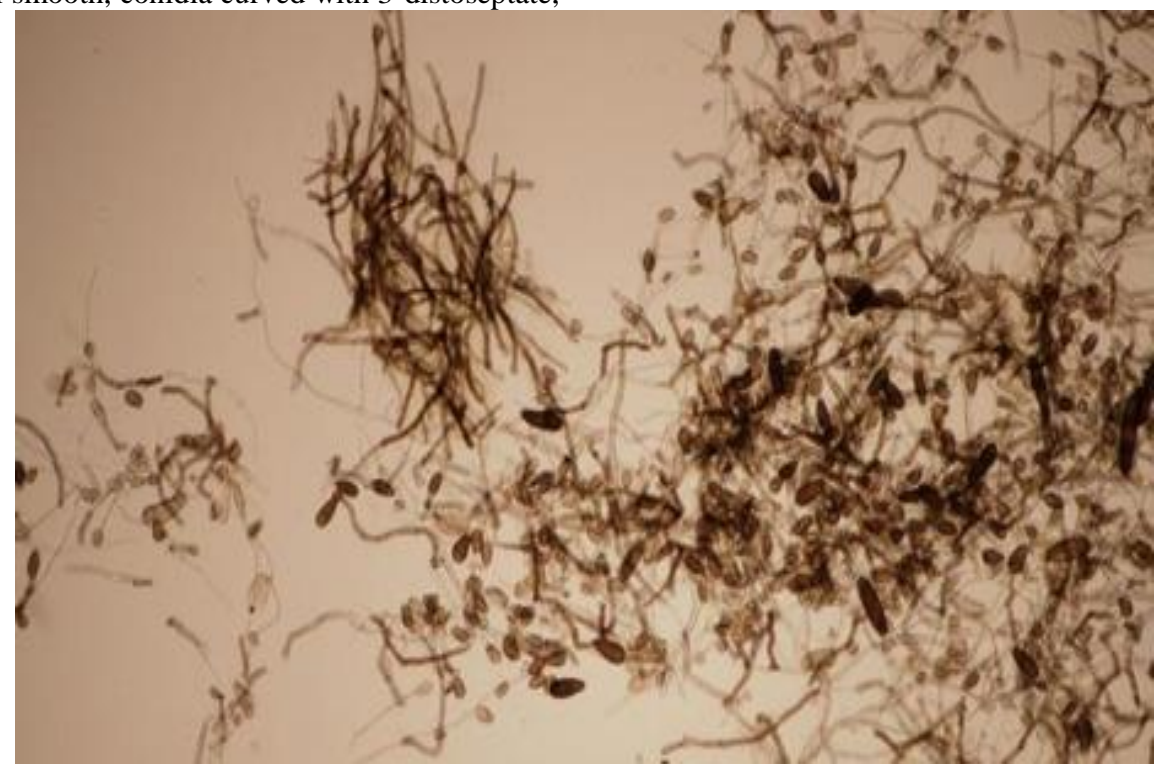

Figure 1. Cochliobolus Sp. On Potato Dextrose Agar (cited in: www.ipmimages.org)

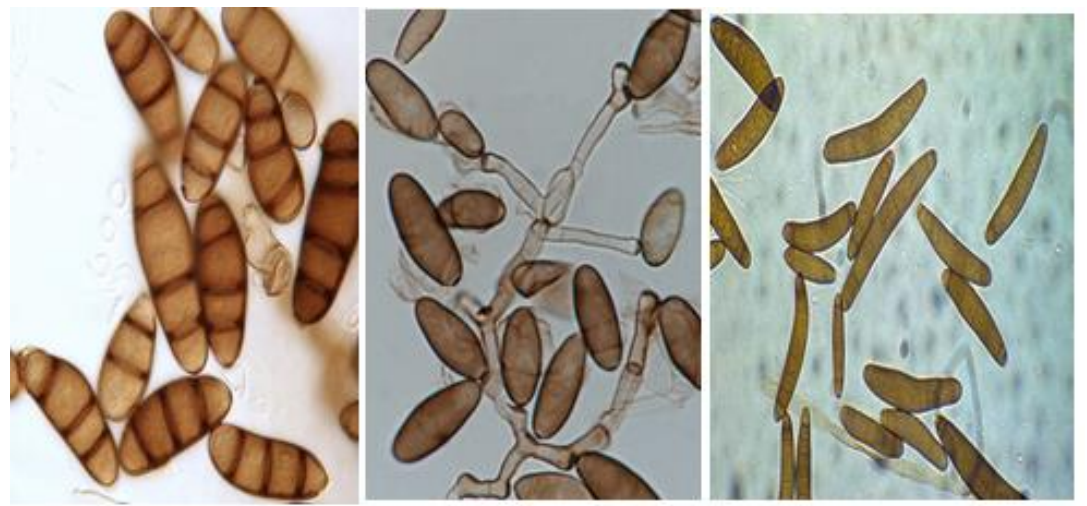

Figure 2. Cochliobolus sp. with different shapes and septate conidia. On Potato Dextrose Agar (cited in: www.sen.wikipedia.org and $w w w$.forestryimages.org).

\section{Cochliobolusis secondary metabolites}

Species of Cochliobolus Drechsler [25] and its anamorphs Bipolaris [20] as well as Curvularia [26, 27] are worldwide pathogens of most grasses. There are a lot of secondary metabolites produced by strains of Cochliobolus and its anamorph. Cochliobolus carbonum produced TOXEp Novel as protein Regulation of cyclic peptide biosynthesis [28], EXG1p novel exo- $\beta 1,3$-glucanase Cell wall degradation. Cochliobolus spicifer which produced spiciferone as AGamma-pyrone as plant growth inhibitor [29] and 6-Chlorodehydrocurvularin [30]. Cochliobolus miyabeanus produced Cochlioquinones A, B compound as new metabolites with p-quinonoid nature [31]. Cochliobolus sativus which produced 9-Hydroxyprehelminthosporol compound which as Anti-viral property [32]. Cochliobolus sp. produced Isocochlioquinone and Cochlioquinone A which as ALeishmanicidal activity [33].

Mycotoxin production by Cochliobolus (Bipolaris species) may or may not be host-specific [19]. HS toxin (a peptide and a secondary amine) produced by Cochliobolus victoriae, HC toxin (a polypeptide) produced by Cochliobolus carbornumrace 1 , and T toxin produced by Cochliobolus hetero-strophusare examples of host-specific toxins. Ophiobolins (terpinoid) produced by Cochliobolus miyabeanus and carbotoxin produced by Cochliobolus carbornumare examples of non-host-specific toxins [19]. Other mycotoxin are Bipolaroxin, Sorokinianin, Carbotoxine, Victorin and Ophiobolin which produced by Cochliobolus. 
The filamentous fungi Cochliobolus sorokiniana efficiently produces the biotransformation of $\alpha$-bisabolol (Figure, 3 ) to bisabolol-oxide B. $\alpha$ Bisabolol is economically significant due to its delicate characteristic floral odor and its anti-inflammatory and antiseptic biological activities. Therefore, it is being widely employed in the pharmaceutical industry.

Potent antifouling activity is observed in some newly isolated resorcylic acid lactones found in the fungus Cochliobolus lunatus derived from the gorgonian Dichotella gemmacea. Thus obtained were cochliomycins AC (Figure, 4). Only cochliomycin A shows potent activity against Balanus amphitrite.

\section{Some biological activities of Cochliobolus metabolites}

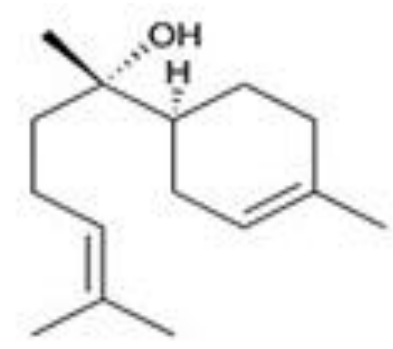

$(-)-\alpha$-Bisabolol
Apart from being a worldwide pathogens of mostly grasses (Poaceae) and important food crops such as rice, wheat and maize [26], Cochliobolus exhibit different activities that can be useful for plants.

For example, Cochliobolus can be used as a biochemical modulator to alleviate

salinity stress in okra plants $[34,35]$. Chloromonilinic acids C and D extracted from Cochliobolus australiensis showed toxic effect to buffelgrass in a seedling elongation bioassay, with significantly delayed germination and dramatically reduced radicle growth, especially at a concentration of $5 \times 10^{-3} \mathrm{M}[36]$.

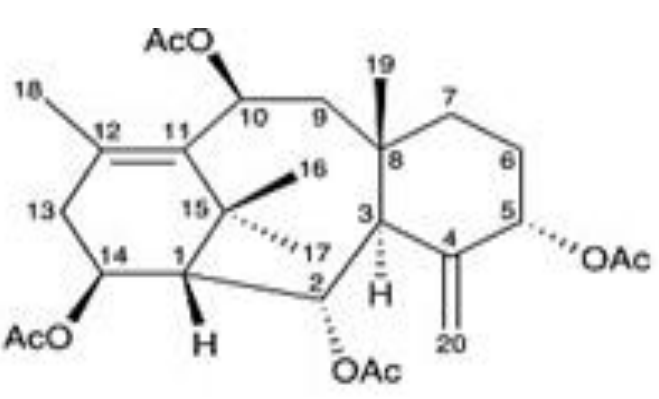

\section{$2 \alpha, 5 \alpha, 10 \beta, 14 \beta-T e t r a a c e t o x y-4(20), 11-t a x a d i e n e$}

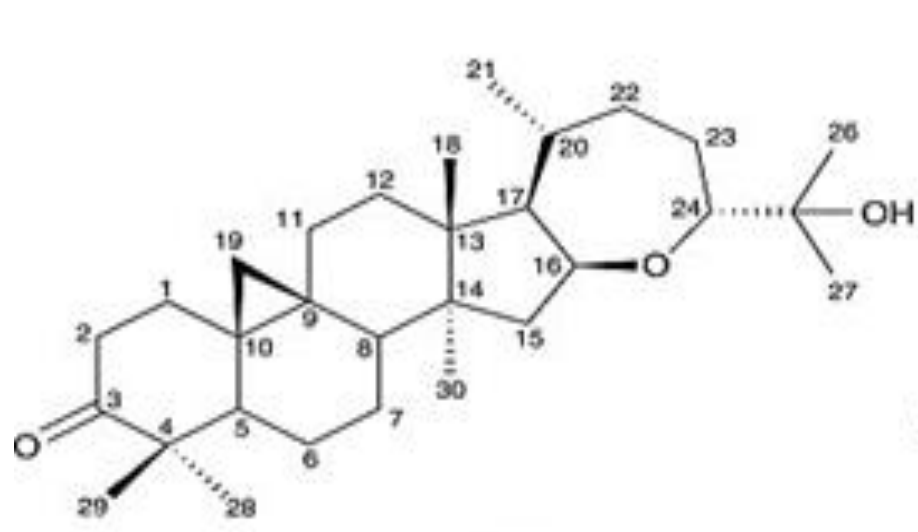<smiles>CC(C)=CCCC(C)C1CCC2(C)C3CCC4C(C)(C)[C@H](O)CCC45C[C@]35CC[C@]12C</smiles>

Argentatin B

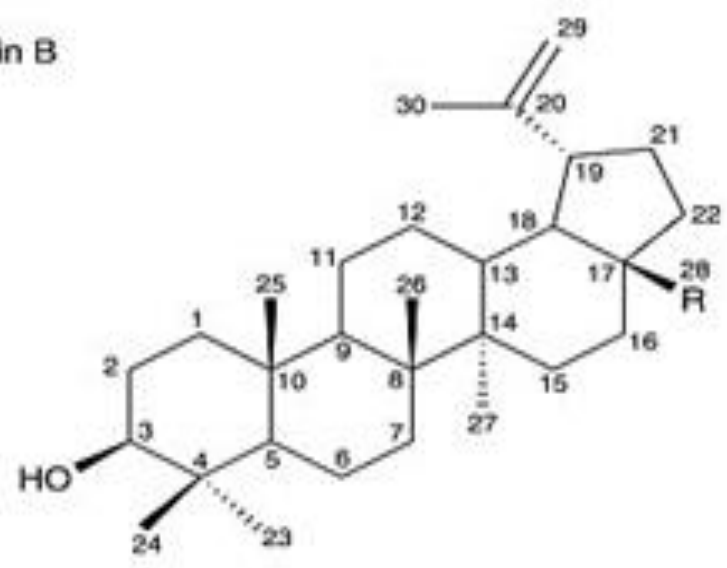

Cycloartenol

$$
\begin{aligned}
& \mathrm{A}=\mathrm{COOH}, \text { betulinic acid } \\
& \mathrm{A}=\mathrm{CH}_{2} \mathrm{OH} \text {, betulin }
\end{aligned}
$$




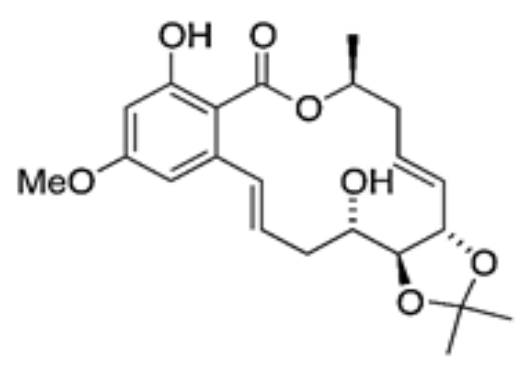

Cochliomucin A<smiles>[GeH2]=[W]</smiles>

Cochliomucin B<smiles>COc1cc(O)c(C(=O)OC(C)C/C=C\C=C/C(O)[C@H](O)C(C)O)c(O)c1</smiles>

Cochliomucin C

Figure 4. Some important structures compounds produced by Cochliobolus lunatus.

On the other hand, Cochliobolus species have well known potency in the field of microbial biotransformation of compounds generally, and steroidal compounds in particular [37, 38].

Furthermore, Cochliobolus species have shown promising various biological activities. Metabolites originated from Cochliobolus exerted antileishmanial activities against Leishmania and Trypanosoma. It was reported that the crude extract of Cochliobolus sp. (UFMGCB-555) at 20 $\mu \mathrm{g} / \mathrm{m}$ concentration could kill $90 \%$ of the amastigote-like forms of Leishmania amazonensis and inhibit by $100 \%$ Ellman's reagent reduction in the trypanothione reductase (TryR) assay, which demonstrated that the chromatographic fractionation of that Cochliobolus sp. extract was a promising drug target for Trypanosoma cruzi. The metabolites, Cochlioquinone A and Isocochlioquinone A were identified as the enzyme inhibitors responsible for the antileishmanial activities [33], [39, 40]. Cochliobolus metabolites showed also promising anticancer activities. Radicinin isolated from Cochliobolus geniculatus WR12 exhibited high cytotoxic activity against T47D cells recording IC 50 of $25.01 \mathrm{ppm}$ [41]. The same compound showed also anti- MRSA activity with minimum inhibitory concentration (MIC) of $125 \mu \mathrm{g} / \mathrm{disc}$ against tested MRSA [42]. Dendryphiellin I isolated from the marine derived Cochliobolus lunatus SCSIO41401 showed cytotoxic activity against three renal cancer cell lines (ACHN, 786-O, and OS-RC-2), a human liver cancer cell line (HepG-2), and a human gastric cancer cell line (SGC7901) (IC50 1.4 to 5.9 and antibacterial activities against three bacterial species (MIC 1.5 to $13 \mu \mathrm{g} / \mathrm{mL}$ ). Another metabolite, (dendryphiellin J), was extracted from the same fungus and showed cytotoxicity against ACHN and HepG-2 cells with IC50 values of 3.1 and $5.9 \mu \mathrm{M}$, respectively [42].

\section{Cochliobolus in biological control}

Cochliobolus species and its asexual states have been isolated as saprobes from different dead wood plants. Also Cochliobolus can be found in association with many species of Poaceae such as bamboo and also other host plants. For example, Curvularia lunata is a frequently recorded saprobe of bamboo clumps [43-45].

Using fungi as biological control agents is a rapidly growing area of research with implication for plant productivity, animal and human health, and food production [46]. Weeds are an economic restraint to agricultural production [47]. Biological control of weeds by using plant pathogens has gained acceptance as a practical, safe, environmentally beneficial weed management method applicable to agroecosystems. The use of mycoherbicides is important in the move towards organic farming and the reduction in the use of chemical herbicides.

Many Cochliobolus and its anamorphic species (Bipolaris and Curvularia) are pathogens of weeds and can successfully be applied as weed herbicides. Some examples of research that shows Bipolaris and Curvularia can be used as potential mycoherbicides. The pathogens may have evolved biochemical mechanisms to kill the weed host [18]. Bipolaris sp. were tested as a potential herbicide agent against serrated tussock in Australia [48]. The biological control of weeds has generally been limited by the slow development of effective, broader spectrum biological control agents $[49,50]$, and more effective biocontrol agents need to be developed.

Curvularides, cochlioquinones, anthroquinones and some novel proteins involved in cyclic peptide regulation and cell wall degradation have been reported from Cochliobolus strains. These compounds may have important medicinal values, such as anti-fungal properties, and thus have the potential to be used in medical science [12]. 


\section{Conclusion}

Fungi are promising sources for such compounds due to their ability to produce variety of secondary metabolites that could be, if truly investigated, the solution for currently serious problems. Every study conducted on Cochliobolus resulted in discovery of new metabolites or pointing to a possible application, which made Cochliobolus species potential source of pharmaceuticals and attracted attention for further investigations of their medical properties.

\section{References}

1. Muria-Gonzalez MJ, Chooi YH, Breen S, Solomon PS. (2015). The past, present and future of secondary metabolite research in the D othideomycetes. Molecular plant pathology, 16(1): 92-107.

2. Elkhateeb WA, Daba GM. (2018). Where to Find? A Report for Some Terrestrial Fungal Isolates, and Selected Applications Using Fungal Secondary Metabolites. Biomed Journal Science \&Technology Research, 4(4): 1-4.

3. Daba GM, Elkhateeb WA, Thomas PW. (2018). This era of biotechnological tools: an insight into endophytic mycobiota. Egyptian Pharmaceu J, 17(3): 121-128.

4. Elkhateeb WA, Zohri AA, Mazen M, Hashem M, Daba GM. (2016). Investigation of diversity of endophytic, phylloplane and phyllosphere mycobiota isolated from different cultivated plants in new reclaimed soil, Upper Egypt with potential biological applications, Inter J MediPharm Res, 2(1): 23-31.

5. Leuchtman A. (2003). In White J, Bacon CW, Hywel-Jones NL, Spatafora JW, eds. Natural products from plant associated endophytic fungi. New York, NY, USA: Marcel-Dekker, 341175.

6. Masi M, Meyer S, Clement S, Pescitelli G, Cimmino A, Cristofaro M, Evidente A. (2017). Chloromonilinic acids C and D, phytotoxic tetrasubstituted 3-chromanonacrylic acids isolated from Cochliobolus australiensis with potential herbicidal activity against buffelgrass (Cenchrus ciliaris). Journal of natural products, 80(10): 2771-2777.

7. He J, Yang MS, Wang WX, Li ZH, Elkhateeb WA, Wen T.C and Feng T. (2019). Anti-phytopathogenic sesquiterpenoid-xanthone adducts from potato endophytic fungus Bipolaris eleusines. RSC Advances, 9(1): 128-131.

8. El-Kassem LA, Hawas UW, El-Souda S, Ahmed EF, El-Khateeb W, Fayad W. (2019). Anti-HCV protease potential of endophytic fungi and cytotoxic activity. Biocatalysis and Agricultural Biotechnology, 101170.

9. Di Pietro A, Gut-Rella M, Pachlatke JP, Schwin FJ. (1992). Role of antibiosis produced by Chaetomium globosum in biocontrol of Pythium ultimum, a causal agent of damping off. Phytopathol. 82: 131-135.

10. Firáková S, Šturdíková M, Múčková M. (2007). Bioactive secondary metabolites produced by microorganisms associated with plants. Biologia, 62(3): 251-257.

11. Selim KA, El-Khateeb WA, El-Beih AA, Tahany M, Eman F. Ahmed and El-Diwany AI. (2018). Antiviral and Antioxidant Potential of Fungal Endophytes of Egyptian Medicinal Plants, Fermentation, 4: 49: 1-11.

12. Chomcheon $\mathrm{P}$, Wiyakrutta $\mathrm{S}$, Aree $\mathrm{T}$, Sriubolmas N, Ngamrojanavanich N, Mahidol C, Kittakoop P. (2010). Curvularides A-E: antifungal hybrid peptide-polyketides from the endophytic fungus Curvularia geniculata. Chemistry-A European Journal, 16(36): 11178-11185.

13. Shoba S, Mythili S. (2018). Biological Activities of Endophytic Fungus Cochliobolus sp. AL24 Isolated from Aerva lanata. L. Indian J Pharmaceu Education Res. 52(2): 277-83.
14. Strobel G, Daisy, B. (2003). Bioprospecting for microbial endophytes and their natural products. Microbiol. Mol. Biol. Rev. 67: 491-502.

15. Schulz B, Boyle C, Draeger S, Rommert AK, Krohn K. (2002). Endophytic fungi: a source of novel biologically active secondary metabolites. Mycol. Res. 106: 996-1004.

16. Aly AH, Debbab A, Proksch P. (2011). Fungal endophytes: unique plant inhabitants with great promises. Appl. Microbiol. Biotechnol. 90: 1829-1845.

17. Campos FF, Ramos JP, De Oliveira DM, Alves TM, De SouzaFagundes EM, Zani CL, Sampaio FC, Converti A, Cota BB. (2017). In vitro leishmanicidal, antibacterial and antitumour potential of anhydrocochlioquinone A obtained from the fungus Cochliobolus sp. J Biosciences. 42(4): 657-664.

18. Strobel G, Kenfield D, Bunkers G, Sugawara F, Clardy J. (1991). Phytotoxins as potential herbicides. Experientia; 47(8): 819-826.

19. Sivanesan A (1987) Graminicolous species of Bipolaris, Curvularia, Drechslera, Exserohilum and their teleomorphs. Mycol. 158: 1-261.

20. Shoemaker RA. (1959). Nomenclature of Drechsleraand Bipolaris, grass parasites segregated from Helminthosporium. Can J Bot. 37: 879-887.

21. Moubasher AH. (1993). Soil fungi in Qatar and other Arab countries. Doha, Qatar: The Scientific And Applied Research Centre University of Qatar; 1993. 566.

22. Elkhateeb WA. (2005). Some mycological, phytopathological and physiological studies on mycobiota of selected newly reclaimed soils in Assiut Governorate, Egypt (M. Sc. Thesis, Faculty of Science, Assuit University, Egypt. 2005; p 238.

23. Murray TD, Parry DW, Cattlin ND. (1998). A color handbook of diseases of small grain cereal crops. Iowa State University Press, Ames, Iowa.

24. Mathre DE. (1987). Compendium of Barley Diseases. American Phytopathological Society, St. Paul, MN.

25. Drechsler C. (1934). Phytopathological and taxonomical aspects of Ophilobolus, Pyrenophora, Helminthosporium and a new genus Cochliobolus. Phytopathol. 24: 973.

26. Manamgoda DS, Cai L, Bahkali AH, Chukeatirote E, Hyde KD. (2011). Cochliobolus: an overview and current status of species. Fungal diversity, 51(1): 3-42.

27. Manamgoda DS, Cai L, McKenzie EH, Crous PW, Madrid H, Chukeatirote E, Hyde KD. (2012). A phylogenetic and taxonomic re-evaluation of the Bipolaris-Cochliobolus-Curvularia complex. Fungal Diversity, 56(1): 131-144.

28. Ahn JH, Walton JD. (1998). Regulation of cyclic peptide biosynthesis and pathogenicity in Cochliobolus carbonum by TOXEp, a novel protein with a bZIP basic DNA-binding motif and four ankyrin repeats. Mol Gen Genet; 260: 462-469.

29. Nakajima H, Fujimoto H, Matsumoto R, Hamasaki T. (1993). Biosynthesis of spiciferone $\mathrm{A}$ and spicifernin, bioactive metabolites of the phytopathogenic fungus, Cochliobolus spicifer. JOrg Chem. 58: 4526-4528.

30. Ghisalberti EL, Rowland CY (1993). 6-chlorodehydrocurvularin, a new metabolite from Cochliobolus spicifer. J Nat Prod. 56: 2175-2177.

31. Carruthers JR, Cerrini S, Fedeli W, Casinovi CG, Galeffi C, Vaccaro AMT, Scala A (1971). Structures of cochlioquinones A and B, new metabolites of Cochliobolus miyabeanus: chemical and X-ray crystallographic determination. J Chem Soc D, 3: 164 166.

32. Aldridge DC, Turner WB (1970). 9-Hydroxyprehelminthosporol, a metabolite of Cochliobolus (Helminthosporium) sativus. J Chem Soc C, 686-688. 
33. Campos FF, Rosa LH, Cota BB, Caligiorne RB, Rabello ALT, Alves TM, Rosa CA, Zani CL. (2008). Leishmanicidal metabolites from Cochliobolus sp., an endophytic fungus isolated from Piptadenia adiantoides (fabaceae). PLoS Negl Trop Dis. 2: $1-11$.

34. Campos FF, Rosa LH, Cota BB, Caligiorne RB, Rabello AL, Alves TM, Rosa CA, Zani CL. (2009). Correction: Leishmanicidal Metabolites from Cochliobolus sp., an Endophytic Fungus Isolated from Piptadenia adiantoides (Fabaceae). PLoS Neglected Tropical Diseases 3(1): 1-10.

35. Bibi N, Jan G, Jan FG, Hamayun M, Iqbal A, Hussain A, Rehman H, Tawab A, Khushdil F. (2019). Cochliobolus sp. acts as a biochemical modulator to alleviate salinity stress in okra plants. Plant Physiol Biochem. 139: pp.459-469.

36. Raghunath R, Radhakrishna A, Angayarkanni J, Palaniswamy M. (2012). Production and cytotoxicity studies of lovastatin from Aspergillus niger PN2 an endophytic fungi isolated from Taxus baccata. Int J Appl Biol. 3: 342-351.

37. Kollerov VV, Shutov AA, Fokina VV, Sukhodol'skaya GV, Gulevskaya SA, Donova MV. (2010). Bioconversion of C 19-and C 21-steroids with parent and mutant strains of Curvularia lunata. Appl Biochem Microbiol. 46(2): 198-205.

38. Chen J, Fan F, Qu G, Tang J, Xi Y, Bi C, Sun Z, Zhang X. (2020). Identification of Absidia orchidis steroid 11ß-hydroxylation system and its application in engineering Saccharomyces cerevisiae for one-step biotransformation to produce hydrocortisone. Metabolic engineering, 57: 31-42.

39. Daba GM. (2009). Microbial Transformation of Cortexolone to Cortisol by Fungi. Master thesis, Ain shams university, Cairo, Egypt.

40. Shao C.-L, Wu H.-X, Wang C.-Y, Liu Q.-A, Xu Y, Wei M-Y, Qian P-Y, Gu Y-C, Zheng C-J, She Z-G. (2011). Potent antifouling resorcylic acid lactones from the gorgonian-derived fungus Cochliobolus lunatus. J. Nat. Prod., 74: 629-633.
41. Handayani D, Putri RA, Ismed F, Hertiani T, Ariantari NP, Proksch P. (2020). Bioactive metabolite from marine spongederived fungus Cochliobolus geniculatus WR12. Rasayan. J. Chem., 13: 417-422.

42. Fang W, Wang J, Wang J, Shi L, Li K, Lin X, Min Y, Yang B, Tang L, Liu Y, Zhou X. (2018). Cytotoxic and antibacterial eremophilane sesquiterpenes from the marine-derived fungus Cochliobolus lunatus SCSIO41401. J Nat Prod.; 81(6): 14051410.

43. Hyde KD, Zhou DQ, McKenzie EH, Ho WH, Dalisay T. (2002) Vertical distribution of saprobic fungi on bamboo culms. Fungal Divers. 11: 109-118.

44. Kodsueb R, McKenzie EH, Lumyong S, Hyde KD. (2008). Diversity of saprobic fungi on Magnoliaceae. Fungal Divers, 30: 37-53.

45. Mohamed R, Jong PL, Zal MS. (2010). Fungal diversity in wounded stems of Aquilaria malaccensis. Fungal Divers, 43: 6774.

46. Butt TM, Jackson CW, Magan N. (2001). Fungi as bio-controlling agents Progress, problem and potential. CABI Publishing, 1-9.

47. Evans HC, Greaves MP, Watson AK. (2001). Fungal biological control agents of weeds: fungi as biocontroling agents progress, problem and potential. CABI Publishing; 2001: 1-9.

48. Casonato S, Lawrie A, McLaren D (2005). Prospects for biological control of serrated tussock. Tussock Terminators Research Forum, 32-35.

49. Zhang ZB, Burgos NR, Zhang JP, Yu LQ. (2007). Biological control agent for rice weeds from protoplast fusion between Curvularia lunata and Helminthosporium Gramineum. Weed Sci. 55: 599- 605.

50. de Hoog GS, Guarro J, Gene J, Figueras M. (2000). Atlas of Clinical Fungi, 2nd ed, vol. 1. Centraalbureau voor Schimmelcultures, Utrecht, The Netherlands, 1-200.
This work is licensed under Creative Commons Attribution 4.0 License

To Submit Your Article Click Here: Submit Manuscript
Ready to submit your research? Choose Auctores and benefit from:

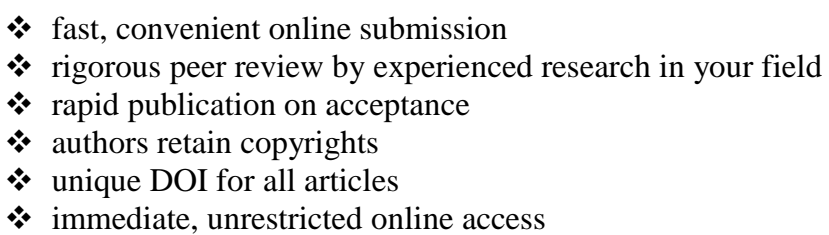

At Auctores, research is always in progress.

Learn more www.auctoresonline.org/journals/pharmaceutics-andpharmacology-research 